\title{
XXIV. On the precipitate produced in spring and river waters by acetate of lead
}

\section{A. Connell Esq.}

To cite this article: A. Connell Esq. (1847) XXIV. On the precipitate produced in spring and river waters by acetate of lead, Philosophical Magazine Series 3, 31:206, 124-125, DOI: 10.1080/14786444708645801

To link to this article: http://dx.doi.org/10.1080/14786444708645801

册 Published online: 30 Apr 2009.

Submit your article to this journal

Џ Article views: 2

Q View related articles $\square$ 
XXIV. On the Precipitate produced in Spring and RiverWaters by Acetate of Lead. By A. Connelu, Esq., Professor of Chemistry in the University of St. Andrewos*.

THE white precipitate which it is well known is usually 1 produced in spring and river waters by acetate of lead, has been commonly attributed to the presence of sulphates, chlorides and carbonates. The comparatively trifling action of silver salts, however, shows that it is very rarely, unless in the case of what are called mineral waters, due to chlorides; and the ready solubility of the precipitate in acetic acid in whole or in great part, proves that it is not due to sulphates or phosphates, except in so far as it may be insoluble in acetic acid. Carbonates therefore remain as the probable cause; and this is established by the circumstance, that although effervescence cannot be noticed on the immediate addition of acetic acid, effervescence will be observed if the precipitate is allowed to subside, and the greater part of the solution decanted, and an acid then added. I have found on investigation that carbonate of lime is the usual source of the reaction. The remarkable fact however on this view is, that the reaction is scarcely diminished by boiling and filtering the water; and indeed in some instances does not take place unless these steps are had recourse to, and acetic acid still dissolves the whole or great part. If the waters referred to are boiled and filtered and then largely concentrated by evaporation, they usually deposit carbonate of lime, and do not indicate any such alka. line reaction as shows an alkaline carbonate. The carbonate of lime causing the reaction is therefore evidently held dissolved in the water independently of the presence of free carbonic acid; and I do not think that chemists, generally speaking, are aware that common water may still retain enough of carbonate of lime to give, with acetate of lead, a considerable precipitate of carbonate of lead, although they may have been boiled and filtered. If in any such case the precipitate should be found to dissolve in acetic acid truly without effervescence, the probable cause would be the presence of a sufficient quantity of some organic matter, such as crenic or apocrenic acid, which precipitates lead salts; for it is not the least likely that fluorine, which has been found in some spring waters, should ever be present in sufficient quantity to affect lead salts, and fluoride of lead would very likely not be soluble in acetic acid.

The question then arises, whence proceeds this carbonate

* Communicated by the Author. 
of lime. To know whether it arises from the water redissolving carbonate of lime, which had been held dissolved by carbonic acid and then precipitated by boiling, I transmitted a current of carbonic acid through lime water till it completely redissolved the precipitate which had at first formed. I then boiled the solution for a short time, as in experimenting with the spring waters, and filtered the liquid; but although it was slightly precipitated by acetate of lead, the effect was very much less than that on common water; showing that we cannot account for the effect on common water by supposing that all the carbonic acid had not been driven off by the ebullition. Again, when distilled water was left in contact with marble in impalpable powder for several days, both acetate of lead and oxalate of ammonia showed less lime than in the common waters, although rather more than in the lime-water experiment. I incline therefore to think that the carbonate of lime owes its origin to double decomposition between an alkaline carbonate and a lime salt, such as a chloride. If to a few ounces of distilled water a drop or two of muriate of lime and a drop or two of carbonate of soda be added, the liquid remains quite transparent; and the reaction of common water with acetate of lead and acetic acid may be exactly imitated with this liquid. And in all the common waters yielding the reaction, I could detect alkalies in union with acids.

The common water of the town of St. Andrews, I found, after being boiled and filtered, to yield by evaporation $3 \frac{1}{3} \frac{1}{2}$ of carbonate of lime; and other well and river waters may contain still more. Fresenius has stated that water is capable of holding in solution $\frac{1}{1} \frac{1}{6} \overline{0} \mathrm{~T}$ of carbonate of lime, after being saturated with that salt by long-continued boiling, and left in contact for four weeks with the deposit formed on cooling. Nature of course does not take such pains to charge spring waters with lime; and I think the method I have suggested affords a much more simple and probable means of effecting this end.

The St. Andrews' water also contains a trace of carbonate of magnesia after being boiled and filtered; and it is probable that this substance may sometimes be in part the cause of the reaction referred to, but to a much less extent*.

* I have given fuller details on this subject in a paper inserted in the Transactions of the Royal Society of Edinburgh for the present year. 